\title{
Adhesive proteins in inflammation process
}

\author{
D. D. Zhernossekov
}

Palladin Institute of Biochemistry NAS of Ukraine

9 Leontovicha Street, Kyiv, 01601, Ukraine

chemikdd@mail.ru

\begin{abstract}
The inflammation process is accompanied by the expression of different adhesive molecules on the surface of both endothelium and blood cells. The adhesion proteins of immunoglobulin, selectin, and integrin family are involved at the certain stages of inflammation response. To cure chronic inflammation processes the selective influence on the molecular mechanism of adhesive interaction of leukocytes is necessary. In the present paper the search for anti-inflammatory anti-adhesive preparations on the basis of structural features of adhesive molecules is discussed.
\end{abstract}

Keywords: selectins, integrins, Ig-CAM, inflammation

The classical scheme of inflammatory reaction development, when leukocytes bind to endothelium and afterwards migrate to inflammation area, was described over 150 years ago. Yet only recently the investigation of CAMs (cell adhesion molecules), providing the interaction of blood cells with endothelium, clarified the underlying molecular mechanisms. There are four stages of inflammatory response, characterized by the expression of certain CAMs [1]. The first stage is called "rolling", specific for leukocytes (monocytes, neutrophils, and lymphocytes) slowing down their movement along the surface of the vessel wall. This

(C) D. D. ZHERNOSSEKOV, 2007 process is mediated by selectins - adhesive proteins capable of binding to carbohydrate ligands on the cell surface [2]. It is remarkable that selectins are expressed by both endothelium and leukocytes. Rolling does not provide firm adhesion of leukocytes to endothelium, but leads to activation of these blood cells and then integrins. Integrins are the next class of CAMs, which take part in the next stage of inflammatory process, i.e. activation of leukocytes and platelets followed by the change in their cell shape.

The third stage is characterized by firm adhesion of leukocytes to endothelium. On the molecular level it is performed via interaction of integrins with adhesive proteins of immunoglobulin superfamily, Ig-CAM. 
During the fourth stage, leukocytes transmigrate through the junctions of endothelial cells to the inflammation site (diapedesis). The proteins of Ig-CAM superfamily are considered to have the main role in this process. Literature data allow reproducing stage-like involvement of adhesive proteins in inflammatory process.

Rolling. This process is not observed without the inflammatory reaction. It is initiated by stimulators, which activate endothelium of vessels. These stimulators are: histamine, thrombin, bradykinin, leukotriene $\mathrm{C} 4$ or free radicals. The number of these agents has increased with the further investigation on the stage of rolling, described in detail in [3]. Activation of endothelium leads to expression of two important members of selectin family, i.e. E-selectin (E-endothelial) and $\mathrm{P}$-selectin (P-platelet). They are also respectively called CD62-E and CD62-P, according to classification of the clusters of differentiation. Despite its name P-selectin is the most important marker of inflammatory state of endothelium.

On the other hand, inflammatory agents stimulate high expression of L-selectin (L-leukocyte), also called CD62-L. Selectins have specific ligands for binding. These ligands are known to be glycoprotein ligand (PSGL) and Lewis tetrasaccharide (CD15S), which contains galactose residues, $\mathrm{N}$-acetylglucosamine, fucose, and sialic acid - for P-selectin; mucine-like endothelium proteins: mucosal addressin MAdCAM, GlyCAM-1, and CD34 - for L-selectin; leukocyte glycoprotein, which contains fucose and sialic acid residues - for E-selectin [3].

It is noteworthy that PSGL can bind all selectin molecules and for all selectins, the presence of sialic acid residue in the structure of ligand is important.

Thus, selectin expression by leukocytes and endothelium provides the slowing down of the blood cell movement along the vessel [4]. Besides, according to some authors, during the stage of rolling the most important event is the expression of P-selectin on the endothelium surface. This protein is released from Weibel-Palade's bodies of endothelial cells and is capable of binding PSGL on the surface of monocytes, neutrophils, and platelets $[5,6]$. Because of proteolytic cleavage, P-selectin is transformed into soluble isoform, sP-selectin ( $\mathrm{s}-$ soluble). On binding monocytes this protein leads to the appearance of tissue factor (coagulation factor) on their surfaces [5]. This event demonstrates close relationship between inflammation and thrombosis.

Selectin adhesion is reversible and unstable, but in the presence of stimulators, selectin rolling activates leukocytes. The details of this process are not clear yet, but the activation process could be represented in the following way. L-selectin binding to the ligand on endothelium surface leads to intracellular release of calcium ions. These ions activate leucocyte integrins and stimulate m-RNA synthesis, which are necessary for synthesis of cytokines [7]. In their turn cytokines activate both endothelium cells and leukocytes, which are not involved in rolling. It is remarkable that leukocyte selectins, binding to ligand on the endothelium surface, form clusters in the regions of cell contact [8]. After integrin activation, these clusters were co-localized with integrin ones.

It is suggested that selectin clustering is a condition for the following activation of integrin adhesive proteins. Simon S. and Green C. made a suggestion of mechanotransducer role of selectins, i.e. of their participation in the process of signal transduction into the cell [1]. The binding of L-selectin to the ligand induces phosphorylation of tyrosin residue in the cytoplasmic domain of the selectin, which in its turn, activates some intracellular kinases and, finally, leads to integrin transformation into high-affinity state and as a result to the firm cell adhesion [9].

Leukocyte activation and integrin transformation into high-affinity state. As it has been mentioned above, rolling and integrin clusterization activate leukocytes. During this process leukocytes change their shape and integrins are converted from low-affinity into high-affinity state, which allows their effective binding to ligands on the neighbouring leukocytes and endothelial cells. Integrins are transmembrane glycoproteins, which contain non-covalently linked $\alpha$ and $\beta$-subunits. The most important integrins, participating in inflammatory response, are $\beta_{2}$-integrins, namely LFA-1 (CD11a/CD18) and Mac-1 (CD11b/CD18) [10, 11]. It was shown that prior to neutrophil activation one cell expresses approximately 15000 sites of Mac-1 and 50000 sites of LFA-1. At these conditions approximately 1000 sites 
of Mac-1 and 9000 sites of LFA-1 are in the high-affinity conformation [12].

The activation of neutrophil is accompanied by the increase in Mac-1 expression up to 140000 sites, but only 13000 of them are in the high-affinity state.

LFA-1 expression has its own peculiarities. During activation of neutrophil, within a few seconds circa $100 \%$ of the whole amount of expressed LFA- 1 is converted into active state. However, LFA-1 binding to ligand is not stable and could be reversed completely within $30 \mathrm{sec}$ after activation of neutrophil. Unlike LFA-1, Mac-1 is capable of supporting active state and interacting with ligand for 10 minutes after activation starts. The conclusion could be made on different functional roles of these two integrins. Apparently, LFA-1 is intended for quick involvement into rolling and for reversible contact of activated leukocyte, while Mac-1 provides long-term firm adhesive contact.

Integrins mediate the contact between leukocytes and platelets $[5,6]$. Here the main role belongs to Mac-1, because of its ability to bind to different ligands. As it was shown in figure, Mac-1 can contact with either other adhesive molecules, for example fibrinogen or vitronectin, or with platelet adhesive protein GP1b.

There is a constant expression of $\beta_{3}$-integrin GPIIbIIIa on the surface of the resting platelet. Selectin rolling can convert platelet into active state and GPIIbIIIa mediates platelet binding to leukocytes via fibrinogen. That is why anticoagulant preparations, which block adhesive action of GPIIbIIIa, possess anti-inflammatory activity as well $[13,14]$.

Interaction of integrins with endothelial adhesive proteins. The main counter-structures for $\beta_{2}$-integrins are endothelial adhesive proteins, which belong to Ig-CAMs. Some of them, for example I-CAM-2, are constantly expressed by endothelial cells, while others (I-CAM-1 and I-CAM-3) are expressed only during the activation of endothelium [15]. I-CAM-1 is the most specific ligand for LFA-1, other ligands (I-CAM-2 and I-CAM-3) are less specific towards this integrin [16]. Besides I-CAMs the cells of activated endothelium are characterized by the expression of another member of Ig-superfamily - V-CAM-1. There are some molecular isoforms of this protein due to alternative splicing. The dominant isoform of V-CAM-1 consists of seven Ig-like domains. The first and fourth domains provide V-CAM-1 binding to VLA-4 integrin on the monocyte surface. After binding to endothelial adhesive proteins, the integrins are redistributed. It was shown that after firm contacts the stretched parts of the neutrophil were drawn inside the cell and there was clustering of LFA-1 and Mac-1 in the contact area $[17,18]$. Apparently, it is the beginning for the new stage.

Diapedesis. This is the least studied stage of the inflammatory reaction. PECAM-1 (platelet-endothelial cell adhesion molecule), the member of Ig-superfamily, is known to be the main adhesive protein of diapedesis. Because of its expression on both leukocyte and endothelium this protein mediates haemophilic contact [19]. In vitro models revealed that antibodies to PECAM-1 suppressed transmigration of leukocytes through the activated endothelial monolayer significantly, while adhesion of neutrophils to endothelium was not disturbed [3]. The whole process of transmigration has not been elucidated yet, but it is assumed that chemotactic stimulus triggers signal transduction via PECAM into the endothelial cell. This process is accompanied by the increase in intracellular calcium and changes in cytoskeleton structure. Finally it leads to the weakening of the contact between endothelial cells.

Modern approaches of using anti-adhesive preparations to block the inflammatory process. Inflammatory reaction is a natural way to protect the organism, but once the reaction becomes chronic, it leads to destruction of healthy tissues and to weakening of immune system. The investigation on the molecular mechanisms of inflammatory reaction is necessary to elaborate new approaches, which allow decreasing adhesive properties of endothelium and/or leukocytes $[21,22]$. The use of monoclonal antibodies to adhesion proteins seems to be the most effective remedy. However, successful application of humanized antibodies to selectins for therapeutic purposes has not been reported. The data on the use of anti-integrin antibodies are of research character only [23].

The approach connected with the use of active and stable analogues of Lewis tetrasaccharide and similar carbohydrate fragments to block selectin rolling is considered to be more promising. 


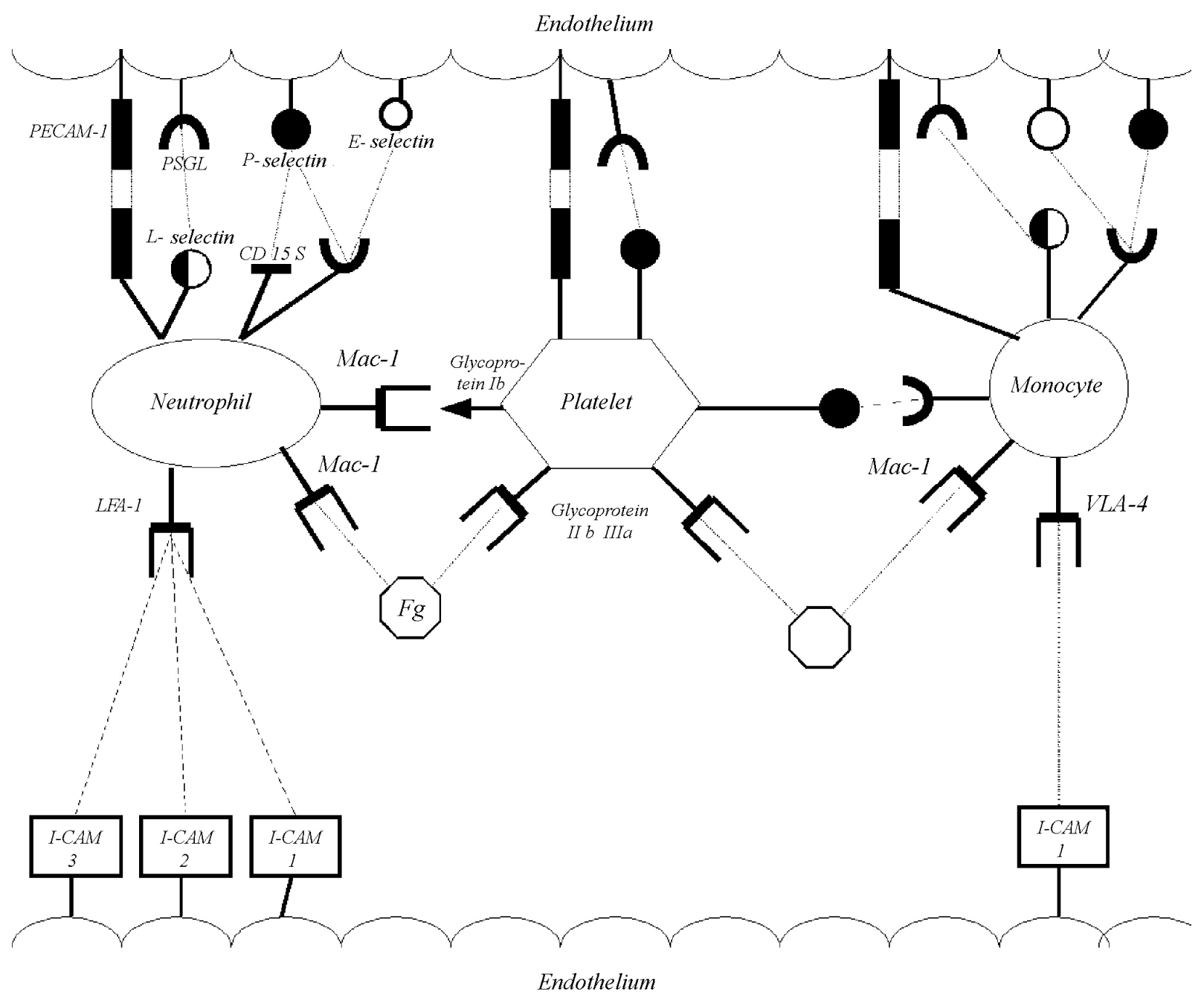

The scheme of interaction of blood cell adhesive proteins with endothelium

Recently Preissner et al. [23] have proposed the use of angiostatin fragments as anti-inflammatory agents. Angiostatin is a proteolytic fragment of plasminogen. Angiostatin or its fragments (first three or the fourth kringle domains) were shown to inhibit the adhesion of leukocyte integrins to I-CAM-1, fibrinogen, and vitronectin. It could be the best solution of this problem, but there is a serious obstacle: plasminogen kringles have high affinity to prion proteins [24].

Concluding on the mentioned above, we can say that structural and functional peculiarities of adhesion proteins and their ligands, the systems of natural proteolysis of these agents have not been elucidated yet. The further investigation in this field could be useful for efficient anti-inflammatory preparations.

\section{Д. Д. Жерносеков}

Адгезивные белки в процессе воспаления

Резюме

При воспалении различные адгезивные молекуль экспрессируются клетками эндотелия $u$ крови. $B$ формирование воспалительного ответа на определенных стадиях прочесса включаются белки адгезии иммуноглобулинового, селектинового и интегринового семейств. В работе охарактеризованы участвующие в воспалительном проиессе адгезивные белки и их лиганды, а также намечены основные пути поиска 
противовоспалительных антиадгезивных препаратов на основе структурных особенностей адгезивных молекул.

Ключевые слова: селектины, интегрины, Ig-CAM, воспаление.

\section{REFERENCES}

1. Simon S. I., Green C. L. Molecular mechanics and dynamics of leukocyte recruitment during inflammation // Annu. Rev. Biomed. Eng.-2005.-N 7.-P. 151-185.

2. Kansas G. S. Selectins and their ligands: current concepts and controversies // Blood.-1996.-N 88.-P. 3259-3287.

3. Albelda S. M., Smith C. W., Ward P. A. Adhesion molecules and infammatory injury // FASEB J.-1994.-N 8.-P. 504512.

4. Rodgers S. D., Camphausen R.T., Hammer D. A. Sialyl Lewis (x)-mediated, PSGL-1-independent rolling adhesion on P-selection // Biophys. J.-2000.-79.-P. 694-706.

5. Струкова С. М. Роль тромбоцитов и сериновых протеиназ в сопряжении свертывания крови и воспаления // Биохимия.-2004.-69, № 10.-С. 1314-1331.

6. Волков Г. Л., Платонова Т. Н., Савчук А. Н., Горницкая О. В., Чернышенко Т. М., Краснобрижая Е. Н. Современные представления о системе гемостаза.-К.: Наук. думка, 2005.-296 c.

7. Brenner B., Kadel S., Birle A., Linderkamp O. L-selectin tyrosine phosphorylates $\mathrm{cb} 1$ and induces association of tyrosine phosphorylated cb1 with crk1 and grb2// Biochem. and Biophys. Res. Communs.-2001.-282.-P. 41-47.

8. Green C. E., Pearson D. N., Christensen N. B., Simon S. I. Topographic requirements and dynamics of signaling via L-selectin on neutrophils // Amer. J. Physiol. Cell. Physiol.2003.-284.-P. 705-717.

9. Waddel T. K., Kialkow L., Chan C. K., Kishimoto T. K., Downey G. P. Signaling functions of L-selectin. Enhancement of tyrosine phosphorylation and activation of MAP kinase // J. Biol. Chem.-1995.-270.-P. 15403-15411.

10. Schmid-Schonbein G. W. Analysis of inflammation // Annu. Rev. Biomed. Eng.-2006.-8.-P. 93-151.

11. Hilden T. J., Nurmi S. M., Fagerholen S. G., Gahmberg C. G. Interfering with leukocyte integrin activation a novel concept in the development of anti-inflammatory drugs // Ann. Med.-2006.-38.-P. 503-511.

12. Lum A. F., Green C. E., Lee G. R., Staunton D. E., Simon S. I. Dynamic regulation of LFA-1 activation and neutrophil arrest on I-CAM-1 in shear flow // J. Biol. Chem.-2002.-277.P. 20660-20670.

13. Mousa S. A. Methods in molecular medicine. Anticoagulants, antiplatelets and thrombolytics.-New York: Humana press, 2004.-320 p.

14. Meyer A., Auernheimer I., Modlinger A., Kesler H. Targeting RGD recognizing integrins: drug development, biomaterial research, tumor imaging and targeting // Curr. Pharm. Design.-2006.-12.-P. 2723-2747.

15. Chen C. C. Signal transduction pathways of inflammatory genes expression and therapeutic implications // Curr. Pharm. Design.-2006.-12.-P. 3497-3508.

16. de Fougerolles A. R., Qin X., Springer T. A. Characterization of the function of intercellular adhesion molecule (I-CAM)-3 and comparison with I-CAM-1 and I-CAM-2 in immune responses // J. Exp. Med.-1994.-179.-P. 619-629.

17. Kim S., Carman C. V., Yang W., Salas A., Springer T. A. The primacy of affinity over clustering in regulation of adhesiveness of the integrin aLb2 // J. Cell. Biol.-2004.-167.-P. 1241-1253.

18. Shav S. K., Ma S., Kim M. B., Rao R. M., Hartman C. U., Froio R. M., Yang L., Jones T., Liu Y., Nusrat A., Parcos C. A., Luscinskas $F$. $W$. Coordinated redistribution of leukocyte LFA-1 and endothelial I-CAM-1 accompany neutrophil transmigration // J. Exp. Med.-2004.-200.-P. 1571-1580.

19. Newman P. J., Newman D. K. Signal transduction pathways mediated by PECAM-1. New roles for an old molecule in platelet and vascular cell biology // Arterioscler. Thromb. Vasc. Biol.-2003.-23.-P. 953-964.

20. Simmons $D$. $L$. What makes a good anti-inflammatory drug target? // Drug Discov. Today.-2006.-11.-P. 210-219.

21. Humby F., Manzo A., Pitzalis $C$. Chemokines in arthritis: key molecules in pathogenesis and potential therapeutic targets // Fut. Rheum.-2006.-1.-P. 53-66.

22. Sims M. J., Hassal D. G., Brett S., Rowan W. A humanized CD 18 antibody can block function without cell destruction // J. Immunol.-1993.-151.-P. 2296-2308.

23. Chavakis T., Athanasopoulos., Rhee J.-S., Orlova V., Schmidt-Woll T., Bierhaus A., May A., Celik I., Nawroth P. P., Preissner K. T. Angiostatin is a novel anti-inflammatory factor by inhibiting leukocyte recruitment // Blood.-2005.-105.-P. 1036-1043.

24. Fischer M. B., Roecki C., Partzek P., Schwarz H. P., Aguzzi $A$. Binding of disease-associated prion protein to plasminogen // Nature.-2000.-408, N 11.-P. 479-483.

UDC 577.112

Received 03.06 .07 